\title{
The Development of Audit Quality Indicators
}

\author{
Dr. Harold T. Little Jr. \\ Associate Professor \\ Western Kentucky University \\ Jenna M. Lehkamp \\ Master of Accounting Student \\ Western Kentucky University
}

\begin{abstract}
Over the years, there has been much debate regarding audit quality. The industry has struggled with how to define audit quality, as well as, how to identify the proper framework and indicators for assessing audit quality. Audit quality gained even more attention after corporate scandals, such as Enron (2001), WorldCom (2002), Tyco (2002), HealthSouth (2003), American Insurance Group (2005), Bernie Madoff (2008) and Lehman Brothers (2011). These scandals shattered the publics' opinion of the accounting and auditing profession and caused investors to question the quality of the audits performed. To date, there is still "little agreement on how to define audit quality, let alone how to measure it" (Dickins et al. 2014, 1). This paper reviews the most recent academic articles published in the top journal during 1981 through 2017.
\end{abstract}

Key words: audit quality indicators; audit quality; assurance; AQI

\section{INTRODUCTION}

Over the years, there has been much debate regarding audit quality. The industry has struggled with how to define audit quality, as well as, how to identify the proper framework and indicators for assessing audit quality. Audit quality gained even more attention after corporate scandals, such as Enron (2001), WorldCom (2002), Tyco (2002), HealthSouth (2003), American Insurance Group (2005), Bernie Madoff (2008) and Lehman Brothers (2011). These scandals shattered the publics' opinion of the accounting and auditing profession and caused investors to question the quality of the audits performed. To date, there is still "little agreement on how to define audit quality, let alone how to measure it" (Dickins et al. 2014, 1).

In an effort to restore the public's confidence in the accounting profession and enhance audit quality, U.S. Congress passed the Sarbanes-Oxley Act of 2002. Under the Sarbanes-Oxley Act of 2002, the responsibilities of the Public Company Accounting Oversight Board (PCAOB) "are all ultimately directed at improving audit quality and thereby benefiting investors" (PCAOB 2015a, 2). With these responsibilities, in November 2012 the PCAOB identified a project that focused on identifying audit quality measures, "with a longer-term goal of tracking such measures with respect to domestic global network firms and reporting collective measures over time." (PCAOB 2012, 5). The project was known as the audit quality indicators (AQI) project.

Initially, the Board has identified over 70 possible AQIs, primarily based on previous studies regarding audit quality. Past research has mainly focused on input-based factors such as audit fees, audit partner tenure, and audit firm size. To further understand the correlation between audit quality and input-based factors, this paper will examine past research studies related to each of the aforementioned factors. By gaining a stronger understanding of these past studies, one will be able to understand the PCAOB's logic for identifying the possible AQIs. 
The remainder of this paper is organized as follows. The next section identifies various definitions of audit quality. The third section provides information from the PCAOB regarding the AQI project. The following section examines factors that affect audit quality by reviewing past research. The fifth section briefly addresses the 28 potential audit quality indicators identified by the PCAOB. The final section includes a brief summary and concluding remarks.

\section{AUDIT QUALITY DEFINED}

Audit quality is an intricate and abstract concept. There has been a great deal of controversy over this topic which is why no universal definition has been recognized. Some of the most commonly recognized definitions of audit quality are those by DeAngelo (1981), the Government Accountability Office (GAO), and the PCAOB.

DeAngelo states, "The quality of audit services is defined to be the market-assessed joint probability that a given auditor will both (a) discover a breach in the client's accounting system, and (b) report the breach" (DeAngelo 1981, 186). According to the GA0, "audit quality refers to the auditor conducting the audit in accordance with Generally Accepted Auditing Standards (GAAS) to provide reasonable assurance that the audited financial statements and related disclosures are (1) presented in accordance with Generally Accepted Accounting Principles (GAAP) and (2) are not materially misstated whether due to errors or fraud" (GAO $2004,6)$. The PCAOB defines audit quality "as meeting investors' needs for independent and reliable audits and robust audit committee communications on: (1) financial statements, including related disclosures; (2) assurance about internal control; and (3) going concern warnings" (PCAOB 2013, 3-4). While these definitions provide some insight into audit quality, the PCAOB believes the AQI project will refine the definition of audit quality and provide a framework that allows audit quality to be more easily measured.

\section{BACKGROUND ON AQI PROJECT}

In an effort to produce higher quality audits, the PCAOB has identified the audit quality indicators project as a priority project beginning in 2013. "The PCAOB's stated purpose of the AQI project is to identify a manageable set of impactful, objective, and measurable indicators that may provide insights into how high quality audits are achieved so that audit firms and audits can be evaluated and compared" (PCAOB 2015b, 1). As previously mentioned, this project will play an integral role in improving overall audit quality within the profession.

According to the PCAOB, audit quality indicators (AQI) are "measures that provide insight into financial statement audit quality" (PCAOB 2013, 1). The U.S. Department of the Treasury's Advisory Committee on the Auditing Profession (2008) has identified two types of AQIs: (1) output-based indicators and (2) input-based indicators. The Advisory Committee provides further explanation regarding the two types of AQIs, stating, "output-based - indicators determined by what the auditing firm has produced in terms of its audit work, and input-based - indicators of what the auditing firm puts into its audit work to achieve a certain result" (Dept. of the Treasury 2008, 116). Such output- and input-based indicators can be further broken down into engagement-level and firm-level indicators (Bedard et al. 2010, C15). Bedard has provided a list that separates audit quality indicators into these four categories (refer to Table 1).

For each of the input-based factors identified in Table 1, there has been a significant amount of research conducted. Such input-based factors are commonly divided into "operational inputs, which largely reflect personnel-driven factors; and process inputs, which largely reflect firm attributes and are intended to roughly align with five components of the Committee of Sponsoring Organizations (COSO) Internal Control Framework" (Dickins et al. 2014, 18). This 
paper will examine the following operational and process input-based factors: (1) audit fees, (2) audit partner tenure, and (3) audit firm size. Research regarding the abovementioned factors has been considered by the PCAOB in developing their list of potential audit quality indicators.

In addition to using previous studies, the PCAOB has used their prior knowledge and experience in developing three main principles that have guided the development of each of the audit quality indicators. The first principle relates to the fact that the AQIs should be quantitative measures, wherever possible, "to add consistency of approach and objectivity to what would otherwise in most situations be only subjective judgments" (PCAOB 2015a, 7). Next, the Board believes AQIs should "generate data that enables users to pose critical questions" (PCAOB 2015a, 7). And finally, the AQIs "should be used and function together as a balanced portfolio of audit quality" (PCAOB 2015a, 7). The Board believes that the AQIs identified should be considered collectively and within a context to obtain their true meaning.

The Board has also identified three primary goals with respect to the AQI project. The project's goals, as identified by the PCAOB, are to: (1) Inform PCAOB regulatory processes and policymaking with additional insight into the status and trends of audit quality; (2) Possibly provide audit committees, investors, management, audit firms, other regulators, and the public with AQIs, providing insight into audit quality for their decisions and policy-making; and (3) Provide firms with additional incentives to compete based on audit quality" (PCAOB 2013, 12). From these goals, one can see that many different users are interested in obtaining information regarding audit quality.

The users interested in the AQI project (refer to Table 2) will range from audit committees to investors to the PCAOB. Each of the identified users will use the audit quality indicators for different reasons. For example, the PCAOB would be interested in the AQIs for obvious reasons such as understanding the factors that affect detection of auditing standards violations. On the other hand, audit committees may be interested in AQIs when evaluating whether or not to retain their current auditors.

Overall, the PCAOB believes the project will "improve the ability of persons to evaluate the quality of audits in which they are involved or on which they rely and to enhance discussions among interested parties" (PCAOB 2015a, 4). The Board also hopes that the AQI project will stimulate competition among audit firms, ultimately resulting in higher quality audits.

\section{POTENTIAL AUDIT QUALITY INDICATORS}

"Understanding the factors that lead auditors to compromise on audit quality is an important issue of concern to scholars, investors, and regulators" (Asthana and Boone 2012, 1). A considerable amount of research has shed light on several factors that affect audit quality. As previously mentioned, Table 1 identifies examples of audit quality indicators, some of which include audit fees, audit partner tenure, and audit firm size. Although there are a vast number of audit quality indicators, this paper will only reference past research affecting the three previously mentioned factors.

\section{Audit Fees and Audit Quality}

Past research presents conflicting evidence regarding the association between audit fees and audit quality. In analyzing audit fees, most research assesses the relationship between abnormal audit fees and audit quality. Thus, a distinction between normal and abnormal audit fees must be made. "Normal audit fees are the expected fees given the client's size, risk, and complexity. The difference between the actual audit fee paid and the fee that was expected 
given the client's size, risk, and complexity is the abnormal component" (Eshleman and Guo 2013, 18). In reviewing the literature (refer to Table 3), two main theories consistently appeared. The two theories identified are commonly referred to as (1) economic bonding and (2) effort view.

First, the idea of economic bonding believes that high abnormal audit fees are generally associated with bribes or client-specific quasi rents that "economically bond the auditor to the client," thus reducing auditor independence (Asthana and Boone 2012, 3). Research in support of the economic bonding theory includes: Asthana and Boone, Choi et al., and Hoitash et al. Asthana and Boone (2012) found that audit quality decreases as positive abnormal audit fees increase by assessing the relationship between abnormally high audit fees and the magnitude of discretionary accruals. Their research found that "greater economic bonding degrades audit quality by impairing auditor independence" (Asthana and Boone 2012,1).

Choi et al. (2010a) also found that abnormally high audit fees are positively associated with the magnitude of discretionary accruals. The positive relationship between audit fees and discretionary accruals suggests a negative association between abnormal audit fees and audit quality. Choi et al. (2010a) also considered the fact that abnormally low audit fees may result in auditors having little reason to compromise audit quality. Ultimately, Choi et al. (2010a) concluded that the "association between abnormal audit fees and audit quality is asymmetric and nonlinear in the sense that the association is conditioned upon the sign of abnormal fees" (p 137).

Hoitash et al. (2007) provides additional support for the economic bonding theory with their research. Their research finds "a significant positive relation between size-adjusted and abnormal total fees paid to the auditor and two metrics used to assess audit quality - an accruals quality measure developed by Dechow and Dichev (2002), as modified by McNichols (2002) and Francis et al. (2005) and the absolute value of performance-adjusted discretionary accruals" (Hoitash et al. 2007, 762). Such findings imply a negative relationship between audit fees and audit quality. After reviewing the literature, it can be said that research in favor of economic bonding suggests that abnormally high audit fees result in lower quality audits.

The second theory, referred to as the effort view, believes that higher audit fees will result in the auditors putting forth greater effort and thus performing a higher quality audit. The research conducted by Eshleman and Guo (2013) support this view by finding "a negative relationship between the level of abnormal audit fees paid by the client and the likelihood of using discretionary accruals to meet or beat the consensus analyst forecast" (117). A negative relationship between abnormal audit fees and discretionary accruals suggests a positive relationship between abnormal audit fees and audit quality. Ultimately, the study found that "abnormal audit fees are an indication of greater auditor effort" (Eshleman and Guo 2013, 135).

Harjoto et al. (2015), relates audit fees and audit quality to the gender and ethnic diversity of CEOs. Their research sees audit fees as a proxy for audit efficiency and audit quality, similar to the effort view theory. The conclusion is that "the presence of female and minority CEOs is associated with greater assurance, leading to higher audit fees" (Harjoto et al. 2015, 969). It was found that female and minority CEOs typically demand greater assurance in order to protect their reputations, reducing the likelihood of accounting errors. However, greater assurance also creates higher audit fees. These higher audit fees are then associated with higher audit quality, concluding that "gender and ethnic diversity could improve audit quality and the firms' overall financial reporting quality" (Harjoto et al. 2015, 963). 
In addition to the two theories previously mentioned, Ettredge et al. (2014) examines "the existence of downward audit fee pressure, and the consequences of fee pressure on audit quality, during the economic downturn that is often referred to as the 'Great Recession'” (247). Using financial reporting misstatements as the proxy, their research found that "downward fee pressure on audit fees is positively associated with decreased audit quality in 2008" (Ettredge et al. 2014, 250). Ettredge et al. considers this association to be restricted to times of economic hardships. However, Asthana and Boone (2012) suggest that auditors may experience pressures during times other than a recession. For example, when negotiations occur between the client and auditor, research has shown that the party with greater bargaining power will win such negotiations. Assuming the client is a large revenue-generating client for the auditor, the auditor may succumb to client's viewpoints. The auditors may feel pressure in this type of situation and may fear that the client will hire different auditors. In this scenario, the client has greater bargaining power and thus expects the auditor to concede. Such research supports the theory on client bargaining power which suggests that audit quality will decrease as negative abnormal audit fees increase. Furthermore, this research shows that downward fee pressure may result in lower quality audits, regardless of the economy.

Hribar et al. (2014) focuses on the relationship between audit fees and accounting quality rather than audit quality. Their research finds that "lower quality accounting systems result in higher fees charged by auditors" (Hribar et al. 2014, 514). When a lower quality accounting system is in place, auditors will be required to compensate with additional effort on their part. In order to balance the added risk and extra audit hours associated with a lower quality accounting system, auditors will increase fees. In addition, Hribar et al. (2014) found that "unexplained audit fees are incrementally informative for predicting restatements, fraud, and SEC comment letters" (536). These factors are generally associated with lower audit quality.

In addition to audit fees, Lim et al. (2012) examines the relationship between audit quality and non-audit fees. Their research finds that "as non-audit fees increase, audit quality reduces only for clients with low institutional ownership but not for clients with high institutional ownership" (Lim et al. 2012, 343). The explanation for this correlation is that clients with high institutional ownership are more likely to monitor the auditors closely, encouraging higher audit quality. The closely monitored auditors will feel more pressure to remain independent and perform well in order to protect their reputation and avoid possible litigation expenses. Therefore, the relationship of audit quality being reduced by non-audit fees exists only for clients with low institutional ownership.

The relationship between audit fees and audit quality has proven to be of particular interest to many researchers. This interest has stemmed from the fact that studies have proven that high abnormal audit fees result in both higher and lower quality audits. In reviewing the literature, it is clear that more than one association exists between audit fees and audit quality and further research is required to resolve these issues.

\section{Audit Partner Tenure and Audit Quality}

Research examining the relationship between audit partner tenure and audit quality also presents conflicting arguments. In studying the literature (refer to Table 4), there are two common views that persist: (1) auditor independence and (2) auditor expertise. The first theory, auditor independence, assumes that as audit partner tenure increases, the partner will build personal relationships with the client, ultimately reducing auditor independence. This theory suggests that the quality of an audit will be lower due to the familiarity threat and lack of auditor independence. The second theory, auditor expertise, believes that the audit partner 
will obtain greater client-specific knowledge, useful in conducting a quality audit, the longer the partner is assigned to the same engagement.

Fargher et al. (2008) and Carey and Simnett (2005) provide support for the auditor independence viewpoint. Fargher et al. (2008) finds "that as audit partner tenure increases, client managers' accounting discretion also increases" (180). This positive relationship is indicative of a negative association between audit partner tenure and audit quality, supporting the auditor independence theory. Carey and Simnett (2005) examine the relationship between audit partner tenure and audit quality through the use of three proxies: (1) "auditors' propensity to issue going-concern audit opinions for distressed companies;" (2) "an examination of the signed and absolute amounts of abnormal working capital accruals;" and (3) "the extent to which key earnings benchmarks are just beaten and just missed" (673). Keeping in mind that the data used for this research was prior to the implementation of mandatory partner rotation, such research concludes that long audit partner tenure impairs audit quality. More specifically, "For the measures of audit quality examining the auditor's propensity to issue a going-concern audit opinion and just meeting (missing) earnings benchmarks, we find evidence consistent with a diminution in audit quality association with long audit partner tenure" (Carey and Simnett 2005, 674).

However, after the implementation of mandatory audit partner rotation, Carey and Simnett's research is revisited by Monroe and Hossain. In contrast to Carey and Simnett's original results, Monroe and Hossain (2013) find a "significant positive association between audit partner tenure when tenure is five years or more and the likelihood of an auditor issuing a going-concern opinion for a financially distressed company" (263). Their research finds that "auditors are more likely to issue qualified going-concern opinions for financially distressed companies when there is a mandatory audit partner rotation after a fixed period of time" (Monroe and Hossain 2013, 263). Thus, their research proves that mandatory audit partner rotation has improved the quality of audits performed and supports the theory of auditor expertise. In addition to Monroe and Hossain's research, Ghosh and Moon and Manry et al. provide empirical evidence in support of the auditor expertise theory.

Ghosh and Moon (2005) "examine whether the extent to which analysts rely on past reported earnings to predict future earnings varies with tenure" (586). Consistent with the auditor expertise theory, their findings conclude "that audited financial statements, and in particular reporting earnings, are perceived as more reliable for firms with longer auditor tenure" (Ghosh and Moon 2005, 609). Manry et al. (2008) find a significant negative correlation between discretionary accruals and audit partner tenure. This relationship suggests a positive association between audit partner tenure and audit quality. Thus, their research supports the auditor expertise viewpoint. Furthermore, their research controls for certain factors, such as client size and engagement risk, and finds that "audit quality increases with partner tenure for small clients, but is unrelated to partner tenure with large clients" (Manry et al. 2008, 554). The research by Manry et al. (2008) also suggests mandatory audit partner rotation may actually reduce audit quality.

Although much research has been conducted over the years relating to the relationship between audit partner tenure and audit quality, such research has only lead to conflicting results. Ultimately, the relationship between audit partner tenure and audit quality is inconclusive.

\section{Audit Firm Size and Audit Quality}

"One of the earliest theories in the audit literature is that Big 4 auditors, due to their larger size 
and better training programs, provide higher audit quality than other auditors" (Eshleman and Guo 2014, 197). The following research (refer to Table 5) supports this theory: Eshleman and Guo (2014), Davidson and Neu (1993), Christensen et al. (2014), Francis and Yu (2009), Choi et al. (2010b), Colbert and Murray (1998), and Meckfessel and Sellers (2017).

Eshleman \& Guo (2014) use "the incidence of accounting restatements as a measure of audit quality" to find that "clients of Big 4 audit firms are less likely to subsequently issue an accounting restatement than are clients of other auditors" (197). Davidson \& Neu (1993) "propose that comparison of management earnings forecasts with audited, reported earnings provides an approach to the measurement of audit quality" (479). Their research suggests that larger auditing firms are generally associated with larger forecast errors, which is consistent with the theory that larger audit firms perform higher quality audits. Christensen et al. (2014), compares the opinions of audit professionals and investors regarding the relationship between audit firm size and audit quality. Their research found that "both groups associate audit firm size with higher audit quality and that investors view frequent audit firm change as an impediment to audit quality" (Christensen et al. 2014, 36).

While most research examines the relationship between audit firm size and audit quality, Francis and Yu (2009) and Choi et al. (2010b) have provided insight on the relationship between the office size of an audit firm and audit quality. Francis \& Yu (2009) "examine the association of office size with going-concern audit reports and client earnings properties" (1522). Their findings suggest that larger Big 4 offices are more likely to issue a going-concern report than other audit offices. Francis and Yu (2009) document "a systematic association between Big 4 office size and audit outcomes consistent with larger offices producing higher quality audits" (1549). Similar to the results of the research performed by Francis and Yu (2009), Choi et al. (2010b) found that "large local offices provide higher-quality audits compared with small local offices" (73). In conducting their research, Choi et al. used unsigned abnormal accruals as the proxy for determining the relationship between office size and audit quality.

Colbert and Murray conducted an analysis on small CPA firms and found results similar to prior research. Colbert and Murray (1998) examined the relationship between audit firm size and audit quality by "measuring auditor quality based on outcomes from the AICPA's Private Companies Practice Section (PCPS) Peer Review Program" (136). Their research found that "even among small CPA firms, size is an indicator of quality for firms that perform audits, reviews, and compilations" (Colbert and Murray 1998, 148).

Instead of focusing on the relationship between audit firm size and audit quality, Meckfessel and Sellers (2017) explore the relationship between consulting practice size and audit quality. Their research found that "consulting practice size has a positive and statistically significant influence on audit reporting lag and restatement rate" (Meckfessel and Sellers 2017, 19), indicating lower audit quality. It was found that when an audit firm has a larger consulting practice size there is a decreased focus on auditing services, resulting in a decrease in audit quality.

The association between audit firm size and audit quality appears to provide more conclusive evidence than audit fees and audit partner tenure that a relationship exists between audit quality and a specific indicator. Based on a review of current literature, one can conclude that there is a positive relationship between audit firm size and audit quality. 


\section{CURRENT STATUS ON AQI PROJECT}

Since the inception of the AQI project, the PCAOB has identified a number of potential audit quality indicators. More recently, the Board has narrowed down the number of audit quality indicators to consist of a list of 28 that they believe will effectively measure audit quality. The framework developed for analyzing audit quality is broken down into three parts: (1) Audit Professionals, (2) Audit Process, and (3) Audit Results. Each of the three sections are further broken down into various subsections. Table 6 outlines the framework and identifies the indicators proposed by the PCAOB. Some of the indicators identified include: staffing level, industry expertise of audit personnel, quality ratings and compensation, and timely reporting of internal control weaknesses.

Of the three audit quality factors addressed in this literature review, only audit fees were directly included in the PCAOB's list of potential indicators. The other two audit quality factors, audit partner tenure and audit firm size, are not explicitly identified in the list of 28 indicators. However, the PCAOB has acknowledged independence requirements, going-concern issues, and industry expertise as potential indicators; all of which were factors discussed in relation to audit partner tenure and audit firm size within this literature review. The studies included in this literature review have not only made significant contributions to enrich research on audit quality, they have also made peer-reviewed contributions to addressing issues raised by the PCAOB's AQI project.

\section{CONCLUSION}

In summary, the research suggests conflicting views with respect to factors affecting audit quality. Although much of the research is inconclusive, the PCAOB believes that the implementation of the AQI project will solve some of the mysteries related to audit quality. The Board hopes that the project will "provide new insights about how to evaluate the quality of audits and how high quality audits are achieved" (PCAOB 2015a, ***). By furthering the development of the AQI project, hopefully one day a universal definition of audit quality will be recognized as well as a proper framework and indicators for assessing the quality of an audit.

\section{References}

Asthana, S. C., and J. P. Boone. 2012. “Abnormal Audit Fee and Audit Quality.” Auditing: A Journal of Practice \& Theory, 1-22.

Bedard, J. C., K. M. Johnstone, and E. F. Smith. 2010. "Audit Quality Indicators: A Status Update on Possible Public Disclosures and Insights from Audit Practice." Current Issues in Auditing, C12-C19.

Carey, P., and R. Simnett. 2006. “Audit Partner Tenure and Audit Quality.” The Accounting Review, 653-676.

Christensen, B. E., S. Glover, T. Omer, and M. Shelley. 2017. “Understanding Audit Quality: Insights from Audit Professionals and Investors." Contemporary Accounting Research, 1-59.

Choi, J., J. Kim, and Y. Zang. 2010a. “Do Abnormally High Audit Fees Impair Audit Quality?” Auditing: A Journal of Practice \& Theory, 115-140.

Choi, J., C. Kim, J. Kim, and Y. Zang. 2010b. “Audit Office Size, Audit Quality, and Audit Pricing.” Auditing: A Journal of Practice \& Theory, 73-97.

Colbert, G., and D. Murray. 1998. "The Association Between Auditor Quality and Auditor Size: An Analysis of Small CPA Firms." Journal of Accounting, Auditing \& Finance, 135-150.

Davidson, R. A., and D. Neu. 1993. "A Note on the Association between Audit Firm Size and Audit Quality." Contemporary Accounting Research, 479-488.

DeAngelo, L. E. 1981. “Auditor Size and Audit Quality.” Journal of Accounting and Economics 3, 183-199.

Department of the Treasury, Advisory Committee on the Auditing Profession. 2008. "Final Report of the Advisory Committee on the Auditing Profession to the U.S. Department of the Treasury." Washington DC: U.S. Department of the Treasury, 1-219. 
Dickins, D., R. G. Fay, and J. Reisch. 2014. "Measuring and Communicating Audit Quality: The New AQIs. The CPA Journal, 16-21.

Eshleman, J. D., and P. Guo. 2013. “Abnormal Audit Fees and Audit Quality: The Importance of Considering Managerial Incentives in Tests of Earnings Management.” Auditing: A Journal of Practice and Theory, 117-138.

Eshleman, J. D., and P. Guo. 2014. “Do Big 4 Auditors Provide Higher Audit Quality after Controlling for the Endogenous Choice of Auditor?" Auditing: A Journal of Practice \& Theory, 197-219.

Ettredge, M., E. E. Fuerherm, and C. Li. 2014. "Fee Pressure and Audit Quality.” Accounting, Organizations and Society, 247-263.

Fargher, N., H.Lee, and V. Mande. 2008. “The Effect of Audit Partner Tenure on Client Managers' Accounting Discretion." Managerial Auditing Journal, 161-186.

Francis, J. R., and M. Yu. 2009. “Big 4 Office Size and Audit Quality.” The Accounting Review, 1521-1552.

Ghosh, A., and D. Moon. 2005. “Auditor Tenure and Perceptions of Audit Quality.” The Accounting Review, 585-612.

GA0. 2004. Public Accounting Firms: Required Study on the Potential Effects of Mandatory Audit Firm Rotation" GAO-04-216. Washington, DC: Government Accountability Office.

Harjoto, M. A., I. Laksmana, and R. Lee. 2015. "The impact of demographic characteristics of CEOs and directors on audit fees and audit delay." Managerial Accounting Journal, 963-997.

Hoitash, R., A. Markelevich, and C. A. Barragato. 2007. “Auditor Fees and Audit Quality.” Managerial Auditing Journal, 761-786.

Hribar, P., T. Kravet, and R. Wilson. 2013. “A new measure of accounting quality.” Review of Accounting Studies, 506-538.

Lim, C. Y., D. Ding, and C. Charoenwong. 2012. "Non-audit fees, institutional monitoring, and audit quality." Review of Quantitative Finance and Accounting, 343-384.

Manry, D. L., T. J. Mock, and J. L. Turner. 2008. “Does Increased Audit Partner Tenure Reduce Audit Quality?” Journal of Accounting, Auditing, and Finance, 553-572.

Meckfessel, M. D. and D. Sellers. 2017. "The impact of Big 4 consulting on audit reporting lag and restatements." Managerial Auditing Journal, 19-49. 


\section{TABLE 1}

Examples of Audit Quality Indicators

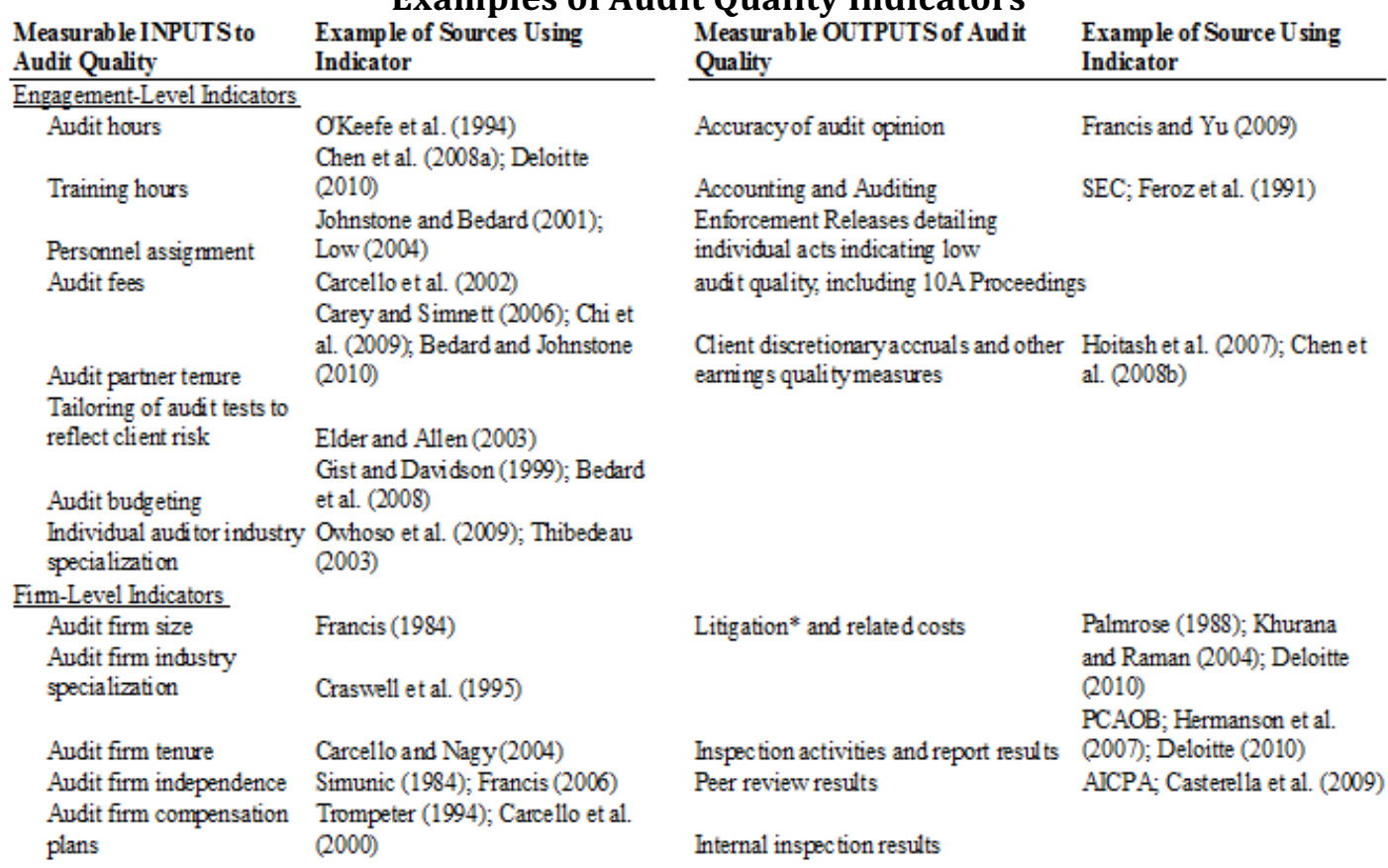

* While we classify litigation as a fim-level indicator, we acknowledge that litigation related to specific engagement maybe linked to the quality of the conduct of individual audit engagements.

**Table directly from, "Audit Quality Indicators: A Status Update on Possible Public Disclosures and Insights from Audit Practice" by Bedard et al. (2010).

TABLE 2

Users of AQIs

\begin{tabular}{|c|c|}
\hline Potential AQI User & $\begin{array}{l}\text { Potential Use (Decisions AQIs Can } \\
\text { Influence) }\end{array}$ \\
\hline Audit Committees & $\begin{array}{l}\text { - Assess reporting risk and audit } \\
\text { quality } \\
\text { - } \\
\text { - } \text { Ovetain and compensate auditors } \\
\end{array}$ \\
\hline Audit Firms & $\begin{array}{l}\text { - Assess and manage risk } \\
\text { - Improve quality control efforts and, } \\
\text { ultimately, audit quality } \\
\text { - Identify root causes of audit } \\
\text { deficiencies and remediate } \\
\text { weaknesses. }\end{array}$ \\
\hline Investors & $\begin{array}{ll}\text { - } & \text { Assess reporting risk } \\
\text { - } & \text { Vote shares } \\
\end{array}$ \\
\hline $\begin{array}{l}\text { PCAOB (and other } \\
\text { Regulators) }\end{array}$ & $\begin{array}{l}\text { - Inform policy-making } \\
\text { - } \\
\text { Assist root cause and quality control } \\
\text { projects } \\
\text { - Stimulate public discussion of, and } \\
\text { market demand for, quality }\end{array}$ \\
\hline
\end{tabular}

**Table directly from PCAOB Release No. 2015-005. 
TABLE 3

Audit Fees and Audit Quality

\begin{tabular}{|c|c|c|c|c|c|}
\hline Author & Purpose & Hypotheses & Method & Sample & $\begin{array}{c}\text { Key } \\
\text { Results/Findings }\end{array}$ \\
\hline $\begin{array}{l}\text { Michael } \\
\text { Ettredge, } \\
\text { Elizabeth } \\
\text { Emeigh } \\
\text { Fuerherm, \& } \\
\text { Chan Li }\end{array}$ & $\begin{array}{l}\text { To investigate } \\
\text { the existence } \\
\text { of downward } \\
\text { audit fee } \\
\text { pressure, and } \\
\text { the } \\
\text { consequences } \\
\text { of that fee } \\
\text { pressure on } \\
\text { audit quality, } \\
\text { during the } \\
\text { economic } \\
\text { downturn. }\end{array}$ & $\begin{array}{l}\text { Downward pressure } \\
\text { on audit fees is } \\
\text { positively associated } \\
\text { with decreased audit } \\
\text { quality in } 2008 \text {. }\end{array}$ & $\begin{array}{l}\text { Mathematical } \\
\text { models and } \\
\text { equations }\end{array}$ & $\begin{array}{l}\text { A sample of all public } \\
\text { companies covered by } \\
\text { both Audit Analytics and } \\
\text { Compustat in } 2008 \text { were } \\
\text { obtained. A final sample } \\
\text { of } 3,039 \text { firms in } 2008 \\
\text { was used to estimate the } \\
\text { fee models needed to } \\
\text { calculate expected audit } \\
\text { fees in } 2008 \text { and the } \\
\text { model used to test the } \\
\text { hypothesis. }\end{array}$ & $\begin{array}{l}\text { The findings suggest } \\
\text { that auditors made fee } \\
\text { concessions to some } \\
\text { clients in 2008, and } \\
\text { that fee pressure was } \\
\text { associated with } \\
\text { reduced audit quality } \\
\text { in that year. }\end{array}$ \\
\hline $\begin{array}{l}\text { Sharad C. } \\
\text { Asthana \& } \\
\text { Jeff P. Boone }\end{array}$ & $\begin{array}{l}\text { To assess the } \\
\text { effects that } \\
\text { abnormal } \\
\text { audit fees have } \\
\text { on audit } \\
\text { quality by } \\
\text { examining } \\
\text { economic } \\
\text { bonding and } \\
\text { client } \\
\text { bargaining } \\
\text { power; } \\
\text { To analyze } \\
\text { pre-SOX and } \\
\text { post-SOX data } \\
\text { to determine } \\
\text { whether the } \\
\text { SoX reforms } \\
\text { increased } \\
\text { audit quality. }\end{array}$ & $\begin{array}{l}\text { H1a: Audit quality will } \\
\text { decline as below- } \\
\text { normal audit fee } \\
\text { increases in } \\
\text { magnitude. } \\
\text { H1b: The association } \\
\text { predicted in H1a will } \\
\text { be amplified as } \\
\text { proxies for client } \\
\text { bargaining power } \\
\text { increase. } \\
\text { H2: Audit quality will } \\
\text { decline as above- } \\
\text { normal audit fees } \\
\text { increase in } \\
\text { magnitude. } \\
\text { H3: The association } \\
\text { between audit quality } \\
\text { and abnormal audit } \\
\text { fees will be attenuated } \\
\text { in the post-SOX period } \\
\text { as compared to the } \\
\text { pre-SOX period. }\end{array}$ & $\begin{array}{l}\text { Mathematical } \\
\text { models and } \\
\text { equations }\end{array}$ & $\begin{array}{l}\text { The sample selection } \\
\text { includes observations for } \\
\text { the period } 2000-2009 \\
\text { available in the Audit } \\
\text { Analytics database for } \\
\text { non-Anderson clients. } \\
\text { The total sample size } \\
\text { used was } 18,873 \\
\text { observations. }\end{array}$ & $\begin{array}{l}\text { This study finds that } \\
\text { audit quality, proxied } \\
\text { by absolute } \\
\text { discretionary accruals } \\
\text { and meeting or } \\
\text { beating analysts' } \\
\text { earnings forecasts, } \\
\text { declines as negative } \\
\text { abnormal audit fees } \\
\text { increase in magnitude, } \\
\text { with the effect } \\
\text { amplified as proxies } \\
\text { for client bargaining } \\
\text { power increase. The } \\
\text { study also concludes } \\
\text { that in years following } \\
\text { the Sarbanes-Oxley } \\
\text { Act (SOX), this effect is } \\
\text { reduced, suggesting } \\
\text { that SOX was effective } \\
\text { in enhancing auditor } \\
\text { independence, thus } \\
\text { audit quality. }\end{array}$ \\
\hline $\begin{array}{l}\text { Rani } \\
\text { Hoitash, } \\
\text { Ariel } \\
\text { Markelevich, } \\
\text { \& Charles A. } \\
\text { Barrangato }\end{array}$ & $\begin{array}{l}\text { To capture the } \\
\text { relation } \\
\text { between audit } \\
\text { quality and } \\
\text { auditor } \\
\text { independence } \\
\text { by examining } \\
\text { fees paid by } \\
\text { firms in the } \\
\text { context of } \\
\text { auditor } \\
\text { profitability. }\end{array}$ & $\begin{array}{l}\text { Principal objective is } \\
\text { to ascertain whether } \\
\text { larger size-adjusted or } \\
\text { abnormal fees result } \\
\text { in a higher or lower } \\
\text { quality audits. }\end{array}$ & $\begin{array}{l}\text { Mathematical } \\
\text { models and } \\
\text { equations }\end{array}$ & $\begin{array}{l}\text { Data was obtained from } \\
\text { Standard \& Poor's Audit } \\
\text { Fee Database. The final } \\
\text { data set consisted of } \\
\text { 13,860 observations. }\end{array}$ & $\begin{array}{l}\text { The key results of this } \\
\text { study find a } \\
\text { significant positive } \\
\text { relation between size- } \\
\text { adjusted and } \\
\text { abnormal total fees } \\
\text { paid to the auditor } \\
\text { and two metrics used } \\
\text { to assess audit quality } \\
\text { - an accruals quality } \\
\text { measure developed by } \\
\text { Dechow and Dichev } \\
\text { (2002), as modified by } \\
\text { McNichols (2002) and } \\
\text { Francis et al. (2005) } \\
\text { and the absolute value } \\
\text { of performance- } \\
\text { adjusted discretionary } \\
\text { accruals during the } \\
\text { period 2000-2003. }\end{array}$ \\
\hline
\end{tabular}




\begin{tabular}{|c|c|c|c|c|c|}
\hline Author & Purpose & Hypotheses & Method & Sample & Key Results/Findings \\
\hline $\begin{array}{l}\text { John } \\
\text { Daniel } \\
\text { Eshleman } \\
\text { \& Peng } \\
\text { Guo }\end{array}$ & $\begin{array}{l}\text { To shed light } \\
\text { on the } \\
\text { conflicting } \\
\text { evidence by } \\
\text { performing a } \\
\text { study of the } \\
\text { relationship } \\
\text { between } \\
\text { abnormal audit } \\
\text { fees and audit } \\
\text { quality using a } \\
\text { new research } \\
\text { design. More } \\
\text { specifically, to } \\
\text { examine } \\
\text { whether clients } \\
\text { paying } \\
\text { abnormal audit } \\
\text { fees are more } \\
\text { or less likely to } \\
\text { use } \\
\text { discretionary } \\
\text { accruals to } \\
\text { meet or beat } \\
\text { the consensus } \\
\text { analyst } \\
\text { forecast. }\end{array}$ & $\begin{array}{l}\text { There was no explicitly } \\
\text { stated hypothesis } \\
\text { within the study. }\end{array}$ & $\begin{array}{l}\text { Mathematical } \\
\text { models and } \\
\text { equations }\end{array}$ & $\begin{array}{l}\text { This study obtained audit } \\
\text { fee and auditor data from } \\
\text { Audit Analytics, financial } \\
\text { statement data from } \\
\text { Compustat and analyst } \\
\text { forecast data from the } \\
\text { I/B/E/S. The study } \\
\text { required firms to have } \\
\text { earnings before } \\
\text { discretionary accruals less } \\
\text { than the consensus } \\
\text { analyst forecast. The } \\
\text { sample amount was } 1,670 \\
\text { firm-year observations } \\
\text { spanning from } 2000- \\
2011 \text {. }\end{array}$ & $\begin{array}{l}\text { The key findings } \\
\text { suggest that clients } \\
\text { paying higher } \\
\text { abnormal audit fees } \\
\text { are less likely to use } \\
\text { income-increasing } \\
\text { discretionary accruals } \\
\text { to meet or beat } \\
\text { earnings targets. This } \\
\text { is consistent with the } \\
\text { notion that abnormal } \\
\text { audit fees are an } \\
\text { indication of greater } \\
\text { auditor effort. }\end{array}$ \\
\hline $\begin{array}{l}\text { Jong-Hag } \\
\text { Choi, } \\
\text { Jeong- } \\
\text { Bon Kim } \\
\& \\
\text { Yoonseok } \\
\text { Zang }\end{array}$ & $\begin{array}{l}\text { To examine } \\
\text { whether and } \\
\text { how audit } \\
\text { quality proxied } \\
\text { by the } \\
\text { magnitude of } \\
\text { absolute } \\
\text { discretionary } \\
\text { accruals is } \\
\text { associated with } \\
\text { abnormal audit } \\
\text { fees, that is, the } \\
\text { difference } \\
\text { between actual } \\
\text { audit fee and } \\
\text { the expected, } \\
\text { normal level of } \\
\text { audit fee. }\end{array}$ & $\begin{array}{l}\text { H1: Abnormal audit } \\
\text { fees are not } \\
\text { significantly associated } \\
\text { with audit quality } \\
\text { when the association } \\
\text { between the two is not } \\
\text { conditioned upon the } \\
\text { sign of abnormal audit } \\
\text { fees. } \\
\text { H2: For clients with } \\
\text { positive abnormal } \\
\text { audit fees, abnormal } \\
\text { audit fees are } \\
\text { positively associated } \\
\text { with the magnitude of } \\
\text { discretionary accruals. }\end{array}$ & $\begin{array}{l}\text { Mathematical } \\
\text { models and } \\
\text { equations }\end{array}$ & $\begin{array}{l}\text { Data was obtained from } \\
\text { the Compustat audit fees } \\
\text { file. The full sample size } \\
\text { consists of } 9.815 \text { firm- } \\
\text { years over the four-year } \\
\text { sample period. }\end{array}$ & $\begin{array}{l}\text { This study finds that } \\
\text { the association } \\
\text { between abnormal } \\
\text { audit fees and audit } \\
\text { quality is asymmetric } \\
\text { and nonlinear in the } \\
\text { sense that the } \\
\text { association is } \\
\text { conditioned upon the } \\
\text { sign of abnormal audit } \\
\text { fees. }\end{array}$ \\
\hline $\begin{array}{l}\text { Paul } \\
\text { Hribar, } \\
\text { Todd } \\
\text { Kravet, \& } \\
\text { Ryan } \\
\text { Wilson }\end{array}$ & $\begin{array}{l}\text { To assess the } \\
\text { relationship } \\
\text { between audit } \\
\text { fees and } \\
\text { accounting } \\
\text { quality and } \\
\text { connect } \\
\text { accounting } \\
\text { quality to } \\
\text { instances of } \\
\text { fraud, } \\
\text { restatements, } \\
\text { and SEC } \\
\text { comment } \\
\text { letters. }\end{array}$ & $\begin{array}{l}\text { Audit fees contain } \\
\text { information about } \\
\text { firms' accounting } \\
\text { quality. }\end{array}$ & $\begin{array}{l}\text { Mathematical } \\
\text { models and } \\
\text { equations }\end{array}$ & $\begin{array}{l}\text { Data was obtained from } \\
\text { various sources. Audit } \\
\text { Analytics was used to } \\
\text { obtain audit fee data. The } \\
\text { Compustat database was } \\
\text { used as well. }\end{array}$ & $\begin{array}{l}\text { This research finds } \\
\text { that unexplained audit } \\
\text { fees contain } \\
\text { information about } \\
\text { firms' accounting } \\
\text { quality. It was also } \\
\text { found that unexplained } \\
\text { audit fees are } \\
\text { incrementally } \\
\text { informative for } \\
\text { predicting } \\
\text { restatements, fraud, } \\
\text { and SEC comment } \\
\text { letters. }\end{array}$ \\
\hline
\end{tabular}




\begin{tabular}{|c|c|c|c|c|c|}
\hline Author & Purpose & Hypotheses & Method & Sample & $\begin{array}{c}\text { Key } \\
\text { Results/Findings }\end{array}$ \\
\hline $\begin{array}{l}\text { Chee Yeow } \\
\text { Lim, David K. } \\
\text { Ding, \& } \\
\text { Charlie } \\
\text { Charoenwong }\end{array}$ & $\begin{array}{l}\text { To examine } \\
\text { the } \\
\text { relationship } \\
\text { between audit } \\
\text { quality and } \\
\text { non-audit fees } \\
\text { as a condition } \\
\text { of institutional } \\
\text { monitoring. }\end{array}$ & $\begin{array}{l}\text { Audit clients with low } \\
\text { institutional } \\
\text { ownership will have } \\
\text { lower audit quality } \\
\text { when non-audit fees } \\
\text { increase than clients } \\
\text { with high institutional } \\
\text { ownership. }\end{array}$ & $\begin{array}{l}\text { Mathematical } \\
\text { models and } \\
\text { equations }\end{array}$ & $\begin{array}{l}\text { The sample included } \\
13,789 \text { firm-years, and } \\
\text { the fee information was } \\
\text { obtained through the } \\
\text { Audit Analytics database } \\
\text { for fiscal years } 2000 \text { - } \\
2001 \text {. }\end{array}$ & $\begin{array}{l}\text { The key findings } \\
\text { suggest that external } \\
\text { monitoring affects the } \\
\text { association between } \\
\text { non-audit fees and } \\
\text { audit quality. The } \\
\text { research indicates } \\
\text { that as non-audit fees } \\
\text { increase, audit quality } \\
\text { is reduced only for } \\
\text { firms with low } \\
\text { institutional } \\
\text { ownership. }\end{array}$ \\
\hline $\begin{array}{l}\text { Maretno Agus } \\
\text { Harjoto, } \\
\text { Indrarini } \\
\text { Laksmana, \& } \\
\text { Robert Lee }\end{array}$ & $\begin{array}{l}\text { To examine } \\
\text { the impact of } \\
\text { gender and } \\
\text { ethnicity of } \\
\text { CEO and audit } \\
\text { committee } \\
\text { members } \\
\text { (directors) on } \\
\text { audit fees and } \\
\text { audit delay in } \\
\text { the US firms. }\end{array}$ & $\begin{array}{l}\text { H1a: CEO gender is } \\
\text { associated with audit } \\
\text { fees. } \\
\text { H1b: CEO ethnicity is } \\
\text { associated with audit } \\
\text { fees. } \\
\text { H2a: The proportion } \\
\text { of female audit } \\
\text { committee members } \\
\text { is associated with } \\
\text { audit fees. } \\
\text { H2b: The proportion } \\
\text { of ethnic minority } \\
\text { audit committee } \\
\text { members is } \\
\text { associated with audit } \\
\text { fees. } \\
\text { H3a: The presence of } \\
\text { a female CEO is } \\
\text { negatively associated } \\
\text { with audit delay. } \\
\text { H3b: The presence of } \\
\text { an ethnic minority } \\
\text { CEO is negatively } \\
\text { associated with audit } \\
\text { delay. } \\
\text { H4a: The proportion } \\
\text { of female audit } \\
\text { committee members } \\
\text { is associated with } \\
\text { audit delay. } \\
\text { H4b: The proportion } \\
\text { of ethnic minority } \\
\text { audit committee } \\
\text { members is } \\
\text { associated with audit } \\
\text { delay. }\end{array}$ & $\begin{array}{l}\text { Mathematical } \\
\text { models and } \\
\text { equations }\end{array}$ & $\begin{array}{l}\text { Data was obtained from a } \\
\text { variety of sources: audit } \\
\text { data from the Audit } \\
\text { Analytics database, } \\
\text { financial data from } \\
\text { Compustat, stock market } \\
\text { data from } \\
\text { Center for Research in } \\
\text { Security Prices (CRSP), } \\
\text { CEO tenure and CEO } \\
\text { turnover data from } \\
\text { Execucomp and director } \\
\text { data from RiskMetrics } \\
\text { Investor Responsibility } \\
\text { Resource Center (IRRC). }\end{array}$ & $\begin{array}{l}\text { This research found } \\
\text { that female CEOs, } \\
\text { ethnic minority CEOs, } \\
\text { and ethnic minority } \\
\text { directors, compared } \\
\text { to male Caucasian } \\
\text { CEOs and directors, } \\
\text { are associated with } \\
\text { higher audit fees. This } \\
\text { implies that gender } \\
\text { and ethnic diversity } \\
\text { in corporate } \\
\text { leadership and } \\
\text { boardrooms could } \\
\text { improve audit quality } \\
\text { and the overall } \\
\text { financial reporting } \\
\text { quality. }\end{array}$ \\
\hline
\end{tabular}


TABLE 4

Audit Partner Tenure and Audit Quality

\begin{tabular}{|c|c|c|c|c|c|}
\hline Author & Purpose & Hypotheses & Method & Sample & $\begin{array}{c}\text { Key } \\
\text { Results/Findings }\end{array}$ \\
\hline $\begin{array}{l}\text { Gary } \\
\text { Monroe } \\
\& \\
\text { Sarowar } \\
\text { Hossain }\end{array}$ & $\begin{array}{l}\text { To investigate } \\
\text { whether audit } \\
\text { partner tenure } \\
\text { and audit qualiy } \\
\text { associations } \\
\text { remain } \\
\text { significant after } \\
\text { the } \\
\text { implementation } \\
\text { of mandatory } \\
\text { audit partner } \\
\text { rotation. }\end{array}$ & $\begin{array}{l}\text { There is a significant } \\
\text { association between } \\
\text { audit partner tenure } \\
\text { and audit quality as } \\
\text { measured by the } \\
\text { propensity of } \\
\text { auditors to issue } \\
\text { going-concern } \\
\text { opinions for } \\
\text { financially distressed } \\
\text { companies. }\end{array}$ & $\begin{array}{l}\text { Mathematical } \\
\text { models and } \\
\text { equations }\end{array}$ & $\begin{array}{l}\text { Audit opinion and audit } \\
\text { partner data are hand- } \\
\text { collected from annual } \\
\text { reports in the } \\
\text { AspectHuntley DatAnalysis } \\
\text { and Connect4 databases. } \\
\text { Financial data are } \\
\text { downloaded from the } \\
\text { AspectHuntley FinAnalysis } \\
\text { database. The final sample } \\
\text { consists of } 4,711 \text { firm-year } \\
\text { observations }\end{array}$ & $\begin{array}{l}\text { The study finds a } \\
\text { significant positive } \\
\text { association between } \\
\text { long audit partner } \\
\text { tenure and the } \\
\text { likelihood of issuing a } \\
\text { going-concern opinion } \\
\text { for a financially } \\
\text { distressed company. } \\
\text { The results provide } \\
\text { evidence of higher } \\
\text { audit quality for } \\
\text { longer audit partner } \\
\text { tenure after the } \\
\text { introduction of } \\
\text { mandatory audit } \\
\text { partner rotation. }\end{array}$ \\
\hline $\begin{array}{l}\text { Peter } \\
\text { Carey \& } \\
\text { Roger } \\
\text { Simnett }\end{array}$ & $\begin{array}{l}\text { To examine the } \\
\text { association } \\
\text { between audit } \\
\text { quality and long } \\
\text { audit partner } \\
\text { tenure by } \\
\text { looking at the } \\
\text { following three } \\
\text { measures: (1) } \\
\text { auditor's } \\
\text { propensity to } \\
\text { issue a going- } \\
\text { concern audit } \\
\text { opinion for } \\
\text { distressed } \\
\text { companies, (2) } \\
\text { the direction and } \\
\text { amount of } \\
\text { abnormal } \\
\text { working capital } \\
\text { accruals and (3) } \\
\text { beating } \\
\text { (missing) } \\
\text { earnings } \\
\text { benchmarks. }\end{array}$ & $\begin{array}{l}\text { There is a negative } \\
\text { association between } \\
\text { audit quality and } \\
\text { long audit partner } \\
\text { tenure. }\end{array}$ & $\begin{array}{l}\text { Mathematical } \\
\text { models and } \\
\text { equations }\end{array}$ & $\begin{array}{l}\text { The data collection for this } \\
\text { study involved the review } \\
\text { and analysis of published } \\
\text { information for public } \\
\text { companies listed on the } \\
\text { Australian Stock Exchange } \\
\text { (ASX) in 1995. A final } \\
\text { sample of 1,021 Australian- } \\
\text { domicile companies was } \\
\text { used. }\end{array}$ & $\begin{array}{l}\text { For the measures of } \\
\text { audit quality } \\
\text { examining the } \\
\text { auditor's propensity to } \\
\text { issue a going-concern } \\
\text { audit opinion and just } \\
\text { meeting (missing) } \\
\text { earnings benchmarks, } \\
\text { we find evidence } \\
\text { consistent with a } \\
\text { diminution in audit } \\
\text { quality associated } \\
\text { with long audit } \\
\text { partner tenure. }\end{array}$ \\
\hline $\begin{array}{l}\text { David L. } \\
\text { Manry, } \\
\text { Theodore } \\
\text { J. Mock \& } \\
\text { Jerry L. } \\
\text { Turner }\end{array}$ & $\begin{array}{l}\text { To examine } \\
\text { whether there is } \\
\text { a relationship } \\
\text { between } \\
\text { evidence of } \\
\text { reduced audit } \\
\text { quality, } \\
\text { measured by } \\
\text { estimated } \\
\text { discretionary } \\
\text { accruals, and } \\
\text { audit partner } \\
\text { tenure with a } \\
\text { specific client. }\end{array}$ & $\begin{array}{l}\text { Audit quality is } \\
\text { reduced as audit } \\
\text { partner tenure with } \\
\text { a client increases. }\end{array}$ & $\begin{array}{l}\text { Mathematical } \\
\text { models and } \\
\text { equations }\end{array}$ & $\begin{array}{l}\text { The firms examined in this } \\
\text { study are a subset of the } \\
\text { sample compiled by Mock } \\
\text { and Turner (2005), who } \\
\text { investigate the relationship } \\
\text { between auditor risk } \\
\text { assessments and audit } \\
\text { program planning } \\
\text { judgments. A sample was } \\
\text { obtained of two years of } \\
\text { data from audits of } 202 \\
\text { clients conducted by three } \\
\text { audit firms. The final } \\
\text { sample for this study was } \\
90 .\end{array}$ & $\begin{array}{l}\text { The key findings } \\
\text { suggest that audit } \\
\text { quality increases with } \\
\text { partner tenure for } \\
\text { small clients, but is } \\
\text { unrelated to partner } \\
\text { tenure for large } \\
\text { clients. It also suggests } \\
\text { that audit partner } \\
\text { rotation may not } \\
\text { increase audit quality } \\
\text { as desired by } \\
\text { Congress, but instead } \\
\text { may actually reduce } \\
\text { audit quality for some } \\
\text { companies. }\end{array}$ \\
\hline
\end{tabular}




\begin{tabular}{|c|c|c|c|c|c|}
\hline Author & Purpose & Hypotheses & Method & Sample & $\begin{array}{c}\text { Key } \\
\text { Results/Findings }\end{array}$ \\
\hline $\begin{array}{l}\text { Neil } \\
\text { Fargher, } \\
\text { Ho- } \\
\text { Young } \\
\text { Lee \& } \\
\text { Vivek } \\
\text { Mande }\end{array}$ & $\begin{array}{l}\text { To examine the } \\
\text { effect of audit } \\
\text { partner tenure } \\
\text { on client } \\
\text { managers' } \\
\text { accounting } \\
\text { discretion. }\end{array}$ & $\begin{array}{l}\text { H1: All else constant, } \\
\text { there is no change in } \\
\text { client managers' } \\
\text { accounting } \\
\text { discretion as audit } \\
\text { partner tenure on an } \\
\text { engagement } \\
\text { increases. } \\
\text { H2: All else constant, } \\
\text { there is no difference } \\
\text { in client managers' } \\
\text { accounting } \\
\text { discretion across } \\
\text { short- and medium- } \\
\text { tenured audit } \\
\text { partners. } \\
\text { H3: All else constant, } \\
\text { there is no difference } \\
\text { in client managers' } \\
\text { accounting } \\
\text { discretion across } \\
\text { medium- and long- } \\
\text { tenured audit } \\
\text { partners. }\end{array}$ & $\begin{array}{l}\text { Mathematical } \\
\text { models and } \\
\text { equations }\end{array}$ & $\begin{array}{l}\text { The initial sample } \\
\text { consisted of the population } \\
\text { of publicly traded } \\
\text { Australian firms that were } \\
\text { publicly traded on the ASX } \\
\text { for which annual reports } \\
\text { were available over the } \\
\text { period 1990-2004. The } \\
\text { annual reports were } \\
\text { obtained from DatAnalysis. } \\
\text { Due to the number of } \\
\text { restrictions, the sample } \\
\text { used in this study } \\
\text { amounted to } 1,306 \text { firms or } \\
12,077 \text { firm-year } \\
\text { observations. }\end{array}$ & $\begin{array}{l}\text { This study finds that, } \\
\text { in the initial years of } \\
\text { tenure of a new audit } \\
\text { partner, client } \\
\text { managers' accounting } \\
\text { discretion decreases } \\
\text { when the new partner } \\
\text { is from the same audit } \\
\text { firm as the outgoing } \\
\text { partner. However, } \\
\text { when the new audit } \\
\text { partner is form a } \\
\text { different audit firm as } \\
\text { the outgoing partner } \\
\text { (audit firm rotation), it } \\
\text { is found that client } \\
\text { managers' accounting } \\
\text { discretion increases in } \\
\text { those initial years. }\end{array}$ \\
\hline $\begin{array}{l}\text { Aloke } \\
\text { Ghosh, } \\
\text { Baruch } \\
\text { College \& } \\
\text { Soocheol } \\
\text { Moon }\end{array}$ & $\begin{array}{l}\text { To examine } \\
\text { whether the } \\
\text { extent to which } \\
\text { analysts rely on } \\
\text { past reported } \\
\text { earnings to } \\
\text { predict future } \\
\text { earnings varies } \\
\text { with tenure. }\end{array}$ & $\begin{array}{l}\text { Reported earnings } \\
\text { are perceived as } \\
\text { being more reliable } \\
\text { as auditor tenure } \\
\text { increases. }\end{array}$ & $\begin{array}{l}\text { Mathematical } \\
\text { models and } \\
\text { equations }\end{array}$ & $\begin{array}{l}\text { The full sample includes } \\
\text { Compustat firms with } \\
\text { available data from } 1990 \text { to } \\
\text { 2000. The restricted } \\
\text { sample consists of firms in } \\
\text { the full sample with } \\
\text { auditor-client relationships } \\
\text { lasting for at least five } \\
\text { years. The maximum } \\
\text { number of observations for } \\
\text { the "restricted" sample was } \\
35,826 \text { firm-years. }\end{array}$ & $\begin{array}{l}\text { In general, most of the } \\
\text { results are consistent } \\
\text { with the hypothesis } \\
\text { that audited financial } \\
\text { statements, and in } \\
\text { particular reported } \\
\text { earnings, are } \\
\text { perceived as more } \\
\text { reliable for firms with } \\
\text { longer auditor tenure. } \\
\text { The study suggests } \\
\text { that imposing } \\
\text { mandatory limits on } \\
\text { the duration of the } \\
\text { auditor-client } \\
\text { relationship might } \\
\text { impose unintended } \\
\text { costs on capital } \\
\text { market participants. }\end{array}$ \\
\hline
\end{tabular}


TABLE 5

Audit Firm Size and Audit Quality

\begin{tabular}{|c|c|c|c|c|c|}
\hline Author & Purpose & Hypotheses & Method & Sample & Key Results/Findings \\
\hline $\begin{array}{l}\text { Gary } \\
\text { Colbert \& } \\
\text { Dennis } \\
\text { Murray }\end{array}$ & $\begin{array}{l}\text { To examine the } \\
\text { relationship } \\
\text { between audit } \\
\text { quality and } \\
\text { auditor size for } \\
\text { small CPA } \\
\text { firms by using } \\
\text { peer review } \\
\text { ratings from } \\
\text { the AICPA's } \\
\text { Private } \\
\text { Companies } \\
\text { Practice } \\
\text { Section }\end{array}$ & $\begin{array}{l}\text { H1: Firm size is } \\
\text { positively associated } \\
\text { with auditor quality. } \\
\text { H2: The number of } \\
\text { previous reviews is } \\
\text { positively related to } \\
\text { audit quality. } \\
\text { H3: Peer review } \\
\text { ratings differ for the } \\
\text { two oversight } \\
\text { organizations. }\end{array}$ & $\begin{array}{l}\text { Mathematical } \\
\text { models and } \\
\text { equations }\end{array}$ & $\begin{array}{l}\text { The study used a } \\
\text { nationwide sample of } \\
422 \text { small CPA firms } \\
\text { selected from the } \\
\text { American Institute of } \\
\text { Certified Public } \\
\text { Accountants' (AICPA) } \\
\text { Private Companies } \\
\text { Practice Section Peer } \\
\text { Review Program }\end{array}$ & $\begin{array}{l}\text { The findings indicate that } \\
\text { audit quality is positively } \\
\text { related to auditor size. } \\
\text { Even among small CPA } \\
\text { firms, size is an indicator } \\
\text { of quality for firms that } \\
\text { perform audits, reviews, } \\
\text { and compilations. }\end{array}$ \\
\hline $\begin{array}{l}\text { Jong-Hag } \\
\text { Choi, } \\
\text { Chansog } \\
\text { (Francis) } \\
\text { Kim, } \\
\text { Jeong- } \\
\text { Bon Kim, } \\
\text { and } \\
\text { Yoonseok } \\
\text { Zang }\end{array}$ & $\begin{array}{l}\text { To investigate } \\
\text { whether and } \\
\text { how the size of } \\
\text { a local practice } \\
\text { office within an } \\
\text { audit firm is a } \\
\text { significant, } \\
\text { engagement- } \\
\text { specific factor } \\
\text { determining } \\
\text { audit quality } \\
\text { and audit fees } \\
\text { over and } \\
\text { beyond audit } \\
\text { firm size at the } \\
\text { national level } \\
\text { and auditor } \\
\text { industry } \\
\text { leadership at } \\
\text { the city or } \\
\text { office level. }\end{array}$ & $\begin{array}{l}\text { H1: Audit quality, } \\
\text { measured by } \\
\text { unassigned abnormal } \\
\text { accruals, is not } \\
\text { associated with the } \\
\text { size of a local } \\
\text { engagement office, } \\
\text { other things being } \\
\text { equal. } \\
\text { H2: Audit fees paid to } \\
\text { auditors are not } \\
\text { associated with the } \\
\text { size of a local } \\
\text { engagement office, } \\
\text { other things being } \\
\text { equal. }\end{array}$ & $\begin{array}{l}\text { Mathematical } \\
\text { models and } \\
\text { equations }\end{array}$ & $\begin{array}{l}\text { The initial sample } \\
\text { consisted of firms } \\
\text { included in the Audit } \\
\text { Analytics database for } \\
\text { the six-year period } \\
\text { from } 2000-2005 \text { for } \\
\text { which data on audit } \\
\text { fees and the location of } \\
\text { city-level audit } \\
\text { engagement offices are } \\
\text { available. After } \\
\text { excluding certain firms } \\
\text { from the sample, the } \\
\text { final sample consisted } \\
\text { of 55,704 firm-year } \\
\text { observations. }\end{array}$ & $\begin{array}{l}\text { First, this study finds that } \\
\text { the office size if positively } \\
\text { associated with audit } \\
\text { quality proxied by } \\
\text { unsigned abnormal } \\
\text { accruals. Second, this } \\
\text { study finds that large local } \\
\text { offices are able to charge } \\
\text { higher audit fees to their } \\
\text { clients than small ones, } \\
\text { which is consistent with } \\
\text { the view that large offices } \\
\text { provide higher quality } \\
\text { audits than small offices. } \\
\text { Overall, the results } \\
\text { suggest that both } \\
\text { regulators and audit firms } \\
\text { should pay more } \\
\text { attention to the behavior } \\
\text { of small offices because } \\
\text { they are more likely to be } \\
\text { economically dependent } \\
\text { on a particular client, and } \\
\text { thus to compromise audit } \\
\text { quality. }\end{array}$ \\
\hline $\begin{array}{l}\text { Ronald } \\
\text { Davidson } \\
\text { \& Dean } \\
\text { Neu }\end{array}$ & $\begin{array}{l}\text { To provide } \\
\text { preliminary } \\
\text { evidence on } \\
\text { the association } \\
\text { between audit } \\
\text { firm size and } \\
\text { audit quality by } \\
\text { using } \\
\text { management } \\
\text { earnings } \\
\text { forecasts as a } \\
\text { benchmark } \\
\text { against which } \\
\text { audit actual } \\
\text { results were } \\
\text { compared. }\end{array}$ & $\begin{array}{l}\text { There was no } \\
\text { explicitly stated } \\
\text { hypothesis within the } \\
\text { study. }\end{array}$ & $\begin{array}{l}\text { Mathematical } \\
\text { models and } \\
\text { equations }\end{array}$ & $\begin{array}{l}\text { The sample used for } \\
\text { this study included } \\
\text { descriptive statistics } \\
\text { from } 112 \text { firms that } \\
\text { applied for an initial } \\
\text { Toronto Stock } \\
\text { Exchange (TSE) listing } \\
\text { between } 1983 \text { and } \\
1987 .\end{array}$ & $\begin{array}{l}\text { Consistent with other } \\
\text { research, this study } \\
\text { suggests that larger } \\
\text { auditing firms are } \\
\text { associated with higher- } \\
\text { quality audits. }\end{array}$ \\
\hline
\end{tabular}




\begin{tabular}{|c|c|c|c|c|c|}
\hline Author & Purpose & Hypotheses & Method & Sample & Key Results/Findings \\
\hline $\begin{array}{l}\text { John Daniel } \\
\text { Eshleman \& } \\
\text { Peng Guo }\end{array}$ & $\begin{array}{l}\text { To reexamine } \\
\text { whether Big } 4 \\
\text { auditors } \\
\text { deliver higher } \\
\text { quality after } \\
\text { controlling for } \\
\text { the } \\
\text { endogenous } \\
\text { choice of } \\
\text { auditor. The } \\
\text { audit quality } \\
\text { proxy chosen } \\
\text { is the } \\
\text { likelihood of a } \\
\text { firm issuing an } \\
\text { accounting } \\
\text { restatement. }\end{array}$ & $\begin{array}{l}\text { H1: Clients of Big } 4 \\
\text { auditors have a lower } \\
\text { likelihood of issuing } \\
\text { an accounting } \\
\text { restatement than } \\
\text { clients of non-Big } 4 \\
\text { auditors after } \\
\text { controlling for the } \\
\text { client's propensity to } \\
\text { choose a Big } 4 \\
\text { auditor. } \\
\text { H2: Clients of the Big } \\
4 \text { have a lower } \\
\text { likelihood of using an } \\
\text { accounting } \\
\text { restatement than } \\
\text { clients of Mid-tier } \\
\text { auditors after } \\
\text { controlling for the } \\
\text { client's propensity to } \\
\text { choose a Big } 4 \\
\text { auditor. }\end{array}$ & $\begin{array}{l}\text { Mathematical } \\
\text { models and } \\
\text { equations }\end{array}$ & $\begin{array}{l}\text { This study obtained } \\
\text { financial statement } \\
\text { data from the } \\
\text { Compustat } \\
\text { Fundamentals Annual } \\
\text { file and auditor and } \\
\text { restatement data from } \\
\text { Audit Analytics for the } \\
\text { period } 200-2009 \text {. The } \\
\text { sample selection } \\
\text { differs for each } \\
\text { hypothesis. To test the } \\
\text { first hypothesis, a } \\
\text { sample of 5,950 } \\
\text { observations were } \\
\text { used. To test the } \\
\text { second hypothesis, a } \\
\text { sample of } 3,248 \\
\text { observations were } \\
\text { used. }\end{array}$ & $\begin{array}{l}\text { This study finds that } \\
\text { clients of Big } 4 \text { auditors } \\
\text { are less likely to } \\
\text { subsequently restate } \\
\text { their earnings than are } \\
\text { clients of non-Big } 4 \\
\text { auditors. We also find } \\
\text { weak evidence that } \\
\text { clients of the Big } 4 \text { are } \\
\text { less likely to issue a } \\
\text { restatement than are } \\
\text { clients of Mid-tier } \\
\text { auditors. Taken together, } \\
\text { the evidence is consistent } \\
\text { with Big } 4 \text { auditors } \\
\text { delivering higher quality } \\
\text { audits. }\end{array}$ \\
\hline $\begin{array}{l}\text { Jere R. } \\
\text { Francis \& } \\
\text { Michael D. } \\
\text { Yu }\end{array}$ & $\begin{array}{l}\text { To analyze the } \\
\text { effects of } \\
\text { client } \\
\text { influence and } \\
\text { auditor } \\
\text { industry } \\
\text { expertise in } \\
\text { individual } \\
\text { practice } \\
\text { offices of Big } 4 \\
\text { accounting } \\
\text { firms and to } \\
\text { investigate a } \\
\text { fundamental } \\
\text { question: Is } \\
\text { Big } 4 \text { audit } \\
\text { quality } \\
\text { uniform across } \\
\text { small and } \\
\text { large practice } \\
\text { offices? }\end{array}$ & $\begin{array}{l}\text { Larger offices of Big } 4 \\
\text { accounting firms } \\
\text { provide higher quality } \\
\text { audits, where higher } \\
\text { quality audits are } \\
\text { inferred by the } \\
\text { auditor's likelihood of } \\
\text { issuing a going- } \\
\text { concern audit report } \\
\text { (and accuracy of the } \\
\text { report in predicting } \\
\text { client bankruptcy), } \\
\text { and the degree to } \\
\text { which clients } \\
\text { evidence earnings } \\
\text { management } \\
\text { behavior. }\end{array}$ & $\begin{array}{l}\text { Mathematical } \\
\text { models and } \\
\text { equations }\end{array}$ & $\begin{array}{l}\text { This study examined a } \\
\text { sample of 6,568 U.S. } \\
\text { firm-year observations } \\
\text { for the period } 2003- \\
2005 \text { and audited by } \\
285 \text { unique Big } 4 \\
\text { offices. }\end{array}$ & $\begin{array}{l}\text { This study suggests a } \\
\text { systematic association } \\
\text { between Big } 4 \text { office size } \\
\text { and audit outcomes } \\
\text { consistent with larger } \\
\text { offices producing higher } \\
\text { quality audits. }\end{array}$ \\
\hline $\begin{array}{l}\text { Brant E. } \\
\text { Christensen, } \\
\text { Steven M. } \\
\text { Glover, } \\
\text { Thomas C. } \\
\text { Omer, \& } \\
\text { Marjorie K. } \\
\text { Shelley }\end{array}$ & $\begin{array}{l}\text { To examine } \\
\text { the thoughts } \\
\text { of audit } \\
\text { professionals } \\
\text { and investors } \\
\text { regarding } \\
\text { audit quality, } \\
\text { specifically } \\
\text { how they } \\
\text { define and } \\
\text { evaluate audit } \\
\text { quality. }\end{array}$ & $\begin{array}{l}\text { There was no } \\
\text { explicitly stated } \\
\text { hypothesis within the } \\
\text { study. }\end{array}$ & $\begin{array}{l}\text { Survey; } \\
\text { Mathematical } \\
\text { models and } \\
\text { equations }\end{array}$ & $\begin{array}{l}\text { This study obtained } \\
\text { usable responses from } \\
96 \text { auditor } \\
\text { participants, } \\
\text { coordinating with the } \\
\text { CAQ's Research } \\
\text { Advisory Board }\end{array}$ & $\begin{array}{l}\text { This study found key } \\
\text { similarities and } \\
\text { differences between the } \\
\text { opinions of auditors and } \\
\text { investors regarding audit } \\
\text { quality. It was found that } \\
\text { both groups associate } \\
\text { audit firm size with } \\
\text { higher audit quality. It } \\
\text { was also found that } \\
\text { investors, more than } \\
\text { auditors, view frequent } \\
\text { audit firm change as an } \\
\text { impediment to audit } \\
\text { quality. }\end{array}$ \\
\hline
\end{tabular}




\begin{tabular}{|l|l|l|l|l|l|}
\hline \multicolumn{1}{|c|}{ Author } & \multicolumn{1}{c|}{ Purpose } & \multicolumn{1}{c|}{ Hypotheses } & \multicolumn{1}{c|}{ Method } & \multicolumn{1}{c|}{ Sample } & \multicolumn{1}{c|}{ Key Results/Findings } \\
\hline $\begin{array}{l}\text { Michele D. } \\
\text { Meckfessel } \\
\text { Sellers }\end{array}$ & $\begin{array}{l}\text { To explore the } \\
\text { relationship } \\
\text { between the } \\
\text { regrowth of } \\
\text { sizable } \\
\text { consulting } \\
\text { practices by } \\
\text { the Big 4 and } \\
\text { audit reporting } \\
\text { lag and } \\
\text { restatement } \\
\text { rates. }\end{array}$ & $\begin{array}{l}\text { Hercent of } \\
\text { revenue from } \\
\text { consulting fees paid to } \\
\text { Big 4 auditors is } \\
\text { positively associated } \\
\text { with audit-reporting } \\
\text { lag. }\end{array}$ & $\begin{array}{l}\text { Models and } \\
\text { equations } \\
\text { H2: Percentage of } \\
\text { revenue from } \\
\text { consulting fees paid to } \\
\text { Big 4 auditors is } \\
\text { positively associated } \\
\text { with restatements. }\end{array}$ & $\begin{array}{l}\text { This study used the } \\
\text { Audit Analytics } \\
\text { database to obtain a } \\
\text { sample of SEC- } \\
\text { registered US audit } \\
\text { clients of the Big 4. }\end{array}$ & $\begin{array}{l}\text { This audit practices are not } \\
\text { immune to the presence } \\
\text { of large consulting } \\
\text { practices within the same } \\
\text { firm. It was found that } \\
\text { consulting practice size } \\
\text { has a positive and } \\
\text { statistically significant } \\
\text { influence on audit } \\
\text { reporting lag and } \\
\text { restatement rate, } \\
\text { indicating lower audit } \\
\text { quality due to decreased } \\
\text { focus on auditing. }\end{array}$ \\
\end{tabular}

TABLE 6

Potential Audit Quality Indicators

\begin{tabular}{|c|c|c|}
\hline \multirow{3}{*}{ 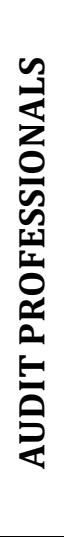 } & Availability & $\begin{array}{l}\text { 1. Staffing Leverage } \\
\text { 2. Partner Workload } \\
\text { 3. Manager and Staff Workload } \\
\text { 4. Technical Accounting and Auditing Resources } \\
\text { 5. Persons with Specialized Skill and Knowledge }\end{array}$ \\
\hline & Competence & $\begin{array}{l}\text { 6. Experience of Audit Personnel } \\
\text { 7. Industry Expertise of Audit Personnel } \\
\text { 8. Turnover of Audit Personnel } \\
\text { 9. Amount of Audit Work Centralized at Service Centers } \\
\text { 10. Training Hours per Audit Professionals }\end{array}$ \\
\hline & Focus & $\begin{array}{l}\text { 11. Audit Hours and Risk Areas } \\
\text { 12. Allocation of Audit Hours to Phases of the Audit }\end{array}$ \\
\hline \multirow{5}{*}{ 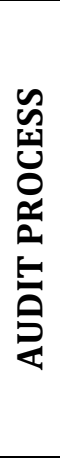 } & $\begin{array}{l}\text { Tone at the Top and } \\
\text { Leadership }\end{array}$ & 13. Results of Independent Survey of Firm Personnel \\
\hline & Incentives & $\begin{array}{l}\text { 14. Quality Ratings and Compensation } \\
\text { 15. Audit Fees, Effort, and Client Risk }\end{array}$ \\
\hline & Independence & 16. Compliance with Independence Requirements \\
\hline & Infrastructure & $\begin{array}{l}\text { 17. Investment in Infrastructure Supporting Quality } \\
\text { Auditing }\end{array}$ \\
\hline & $\begin{array}{l}\text { Monitoring and } \\
\text { Remediation }\end{array}$ & $\begin{array}{l}\text { 18. Audit Firms' Internal Quality Review Results } \\
\text { 19. PCAOB Inspection Results } \\
\text { 20. Technical Competency Testing }\end{array}$ \\
\hline \multirow{5}{*}{ 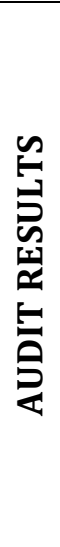 } & Financial Statements & $\begin{array}{l}\text { 21. Frequency and Impact of Financial Statement } \\
\text { Restatements for Errors } \\
\text { 22. Fraud and other Financial Reporting Misconduct } \\
\text { 23. Inferring Audit Quality from Measures of Financial } \\
\text { Reporting Quality }\end{array}$ \\
\hline & Internal Control & 24. Timely Reporting of Internal Control Weaknesses \\
\hline & Going Concern & 25. Timely Reporting of Going Concern Issues \\
\hline & $\begin{array}{l}\text { Communications } \\
\text { between Auditors and } \\
\text { Audit Committee }\end{array}$ & $\begin{array}{l}\text { 26. Results of Independent Surveys of Audit Committee } \\
\text { Members }\end{array}$ \\
\hline & $\begin{array}{l}\text { Enforcement and } \\
\text { Litigation }\end{array}$ & $\begin{array}{l}\text { 27. Trends in PCAOB and SEC Enforcement Proceedings } \\
\text { 28. Trends in Private Litigation }\end{array}$ \\
\hline
\end{tabular}

**Table directly from PCAOB Release No. 2015-005 